\title{
Spade and Screen
}

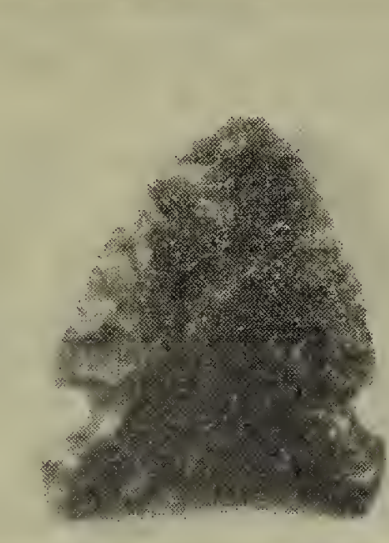

\section{BOOK REVIEW}

\section{THE MORTLACH SITE}

1955. BOYD N. WETTLAUFER

Published 1956, Queens Printer, Regina. Department of Natural Resources, Anthropological Series No. 1.

The first published report of a scientific archaeological excavation in Saskatchewan is an attractive paper-bound book which should be made available to everyone interested in Plains archaeology. Since this is at present the only report available for the Northern Plains region it should receive much attention.

The study is divided into three major portions: Part 1 - the excavation; Part 2 - Physical features and soils of the Mortlach archaeological area (by H. C. Moss - Saskatchewan Soil Survey); Part 3 - Summary and conclusions. A good table of contents, 11 illustrations and 12 figures are a great help to the reader.

The report opens with a detailed description of the field techniques employed at the several points of excavation upon which the study is based. The difficulties and painstaking work essential to a serious archaeological investigation are very clearly indicated. The Mortlach Site is a particularly complicated stratified site.

The cultural material from each level has been named by $\mathrm{Mr}$. Wettlaufer and is discussed separately, beginning with the topmost level and progressing downwards to the lowest and oldest level. The study embraces cultures covering a period of more than 3000 years, the earliest date of 1445 B.C. and two other dates having been established by Carbon14 dating. Seven different cultures have been named, four of these each being divided into two or more levels, a separation based, in part on a careful analysis of the soils by $\mathrm{H}$. C. Moss.

Grit-tempered, stamped and cordmarked pottery was found in the four upper levels ("Mortlach" and "Moose Jaw" cultures). Projectile points were found in all levels and ranged from small side-notched triangulars in the topmost level through a variety of side-notched, stemmed and corner-notched kinds - all of which are well illustrated in the plates.

The projectile point types would have a greater significance if a larger number of each kind had been found. Unfortunately, only one or two points are available for some levels and comparisons with other sites on this basis will be difficult. As the author points out, future excavations will be required to describe each culture more fully.

The soils survey appears to have been handled very competently. This material is considered in a discussion of the geological significance of the Mortlach levels. Geology, climate and the activities of man are finally interrelated in the summary of the paper. A detailed and instructive review of the cultures (including a useful chart) is presented in the summary. The paper concludes with an important statement on the "potentialities of Saskatchewan archaeologically" which should be read by every interested person in the province. The author has done a fine job with a site which presented many difficulties. As an initial study in an archaeologically unknown area it will stand as a landmark of personal endeavor and governmental vision.

There is little doubt that this (Continued on poge 136) 


\section{Registration at the Annual Meeting}

Registered at the annual meeting of the Saskatchewan Natural History Society October 26 and 27 were 67 persons from one Manitoba and 19 Saskatchewan points. From Regina: Mrs. W. K. Cruickshank, J. H. Hudson, Pearl Guest, Mr. and Mrs. G. W. Stewart, Dr. and Mrs. G. Ledingham, Beattie Ledingham, E. L. Fox, F. H. Brazier, Edna Colbeck, Mrs. L. Lamont, L. T. Carmichael, Margaret Belcher, Mr. and Mrs. J. Hodges, G. Weighill, Mr. and Mrs. F. Robinson, Mr. and Mrs. B. Knox, Keith Knox, Marguerite Robertson, Mrs. M. Willers, Blodwen Davies, Mrs. T. Shoyama, Lucy Murray, Mr. A. Foster, Dr. R. W. Nero; from Saskatoon: J. Shadick, Mr. and Mrs. A. Dzubin. Mrs. J. W. Gerrard, R. B. Pravda, F. Roy, Helen Mann, Betty Long, Dr. R. M. Bremner; from Yorkton: Dr. and Mrs. C. S. Houston, Mr. and Mrs. C. Shaw; from Prince Albert: E. W. Brooman, E. Capusten; from Moose Jaw: Mrs. F. McLaughlin, Mr. and Mrs. A. J. Rankin; from Swift Current: A. C. Budd; from Spirit Lake: Mrs. J. A. Gunn, W. Anaka, Donna Anaka; from Canora: Nena Skurat; from Tisdale: K. E. Baines; from Naicam: W. Yanchinski; from Piapot: Mr. and Mrs. S. Mann, Robert Mann, Harry Williams; from Hazelcliffe: J. Provick; from Keatley: A. P. Pym; from Indian Head: Mrs. R. McLaughlin; from Lockwood: $R$. B. Willems; from Fairy Hill: Mrs. C. A. Stewart; from Rocanville: Mrs. E. D. Sutton; from McLean: Mrs. Harold Bray; from Neudorf: Ray Elmore; from Lac du Bonnet, Manitoba: L. Wojciechowski.

\section{THE MORTLACH SITE}

(Continued from poge 133)

publication will increase interest in scientific archaeology. It is hoped that the issuance of this report will be met by a renewed wave of enthusiasm on all sides and will result in a further consideration of the need for a provincial archoeologist. We possess, as part of our cultural heritage, a prehistory in Saskatchewan of at least 10,000 years and possibly twice that figure. The gradual unfolding of this story will add immeasurably to the development of Canadian culture.

Note: Copies of THE MORTLACH SITE may be had upon request to the Saskatchewan Museum of $\mathrm{Na-}$ tural History. The supply is limited.

\section{NOTES AND REQUESTS}

MRS K. H. SKINNER of Indian Head writes re: the annual meeting, "May I say how much we enjoyed the meeting on Saturday-every aspect of it." She also tells how to keep House Sparrows from eating the suet pist out for Chickadees. Sparrows, ine finds, eat only ground suet, so she pushes chunks of suet on three spikes driven through a piece of wood.

SMALL SANCTUARIES: $M r$. and Mrs. W. Ranson of Minitonas, Man., wrote telling us how they learned of the Blue Jay through the Dauphin
Sportsmen's Panel on radio CKDM. The Ransons have always been conservationists. They try to keep part of their farm in its natural condition where wildlife may find shelter and might sometimes be seen and enjoyed by man. The trouble is that land is taxed in proportion to its soil fertility. The person who owns land must break it and crop it or the taxes will break him. The Ransons suggest that while our granaries are full of wheat that we cannot sell surely now is the time for us to work for the development of small tax-free sanctuaries.

SHORT-TAILED SHREW - A specimen of Short-tailed Shrew (Blarina brenicanda) has been received from $\mathrm{Mr}$. Robert Levick. Collected by his cat at Porcupine Plains on August 6, 1956.

R. W. Nero.

REQUEST SILVER-HAIRED BAT resords for coming distribution study. Write R. W. Nero, Saskatchewan Museum of Natural History, Regina.

REQUEST RECORDS OF EUROPEAN STARLING (Sturnus vulgaris) - In order to establish the weistern movement of the European Starling, M. T. Myres, Department of Zoology, University of British Columbia, Vancouver, would like to have notes on the occurrence of the Starling, appearance and nest dates, and would be glad to get specimens to support these records. 